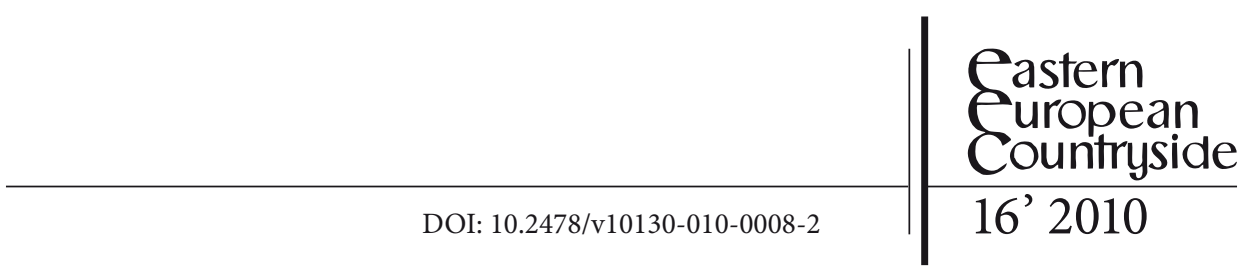

Krisztina Jász

\title{
Poverty and Social Exclusion in the Rural Areas of Hungary
}

\begin{abstract}
The study analyses the role of - two so-called collective factors - spatiality and ethnicity in social exclusion in Hungary. Furthermore, it highlights the unfavourable effects of incorrect political decisions concerning regional development on rural poverty and exclusion in Hungary's history since the end of World War II. It suggests the need for a new practice of monitoring and focused reporting at micro-regional level, close cooperation of regional development and social policy actors in regional planning, as well as a definite commitment of local decision makers in order to reduce spatial inequalities and avoid further escalation of exclusion.
\end{abstract}

Keywords: social exclusion, rural poverty, collective factors, ethnicity, spatiality, peripherisation, cohesion policy, cooperation, monitoring.

\section{Introduction}

Researchers striving to commit to paper something about poverty and social exclusion in rural areas face a true challenge. A major obstacle for comprehending and tackling these issues is the lack of an underlying single order of definitions and indicators.

Readers thumbing through "Combating Poverty and Social Exclusion in Rural Areas", the most recent EU document on this topic, will soon realise that, in it, equal length has been devoted to arguments urging more efficient intervention measures and a remedy to this situation, and to information that offers an insight into the characteristics of poverty in rural areas in the EU. Of course, we are not suggesting that no research worthy of mention has 
been conducted to explore social exclusion and poverty in rural areas over the last decades in Europe; nevertheless, some fundamental issues are still on the to-do list, which suggests serious shortcomings. Although I would like to resist the temptation to play the populist card, we should remember that underlying our fudgy terms, definitions and indicators are flesh-and-blood people, and nearly 80 million of them live in poverty in the 27 member states of the European Union, with an overwhelming majority in rural areas. This is one of the reasons why a clarification of methodological issues is so pressing today.

Naturally, the shortcomings mentioned in my first few sentences do not turn our ambitions into a Mission Impossible; there is no denying that they limit the truth and validity of our study. In the light of the above, all that is left for us to say is that by addressing social exclusion and poverty in the rural areas of Hungary, and using the relevant definitions we will accept the tenet put forward by Littlewood and Herkommer (Littlewood 1999) the essence of which says that poverty and social exclusion are concepts for which there is no professional consensus, and which are used to mean a number of things. Accordingly, we will use the terms 'social exclusion' and 'poverty' as synonyms here.

\section{The Role of Spatiality and Ethnicity, the Two Collective Factors in Social Exclusion in Hungary}

Since the political changeover, numerous studies have confirmed that the overwhelming majority of social and economic disadvantages emerge in a spatial context, the underlying reason for which is that space - as a dimension vested with special characteristics - is capable of creating favourable and unfavourable situations by itself. The spatial units where the economy is underdeveloped, where the unemployment rate is high and the cultural and ethnic differences of the population relative to social mainstreams are significant, are areas ripe for social exclusion. These phenomena are most common in diverging disadvantaged areas (Faluvégi 2004). Nowhere else in Europe is the combined effect of these two factors as strong as it is in Hungary. History and political mistakes are both to be blamed.

In the following section we will provide an overview of the impact of these two general factors (Szalai 2002), i.e. spatiality and ethnicity, on trends in poverty. 


\section{The Role of Spatial Inequalities in Social Exclusion}

The trend in social development after World War II - which was the hardest to rectify - was the excessive amplification of the spatial inequalities that had developed over the centuries (Szalai 2002). Before, however, going on to provide an overview of the major milestones during the period from the beginning of World War II to the present, we will provide a brief summary of the stages leading to the evolution of the country's internal and external peripheries, because this is how we can understand how the mistakes of spatial policy in the past 65 years have aggravated an already disadvantaged situation. We will use the example of the Great Plain to illustrate the evolution of the peripheries in Hungary, as it is here that expanses of rural small regions exhibiting the characteristics of periphery are the largest (Jász 2006).

A key event in the history of the evolution of peripheries along the border was the 1921 Trianon Treaty that concluded World War I, which reduced the territory of Hungary to one-third of its original size. In the wake of the finalisation of the new borders, what had been left from the truncated counties started to develop into a backward rural zone that began mainly along the Northern and Eastern borders. After the Trianon Pact, the Great Plain was shorn of half of its original territory, as a result of which market towns, crucial to agrarian production and the sale of the products, now lay outside Hungary. So were manufacturing units representing the beginnings of industrial production. We think that, in addition to the above, regarding the spatial aspects of social exclusion, the political decision after World War I had another outcome, one that still resonates and was a fatal blow to the accessibility of the region. Trianon also stripped border regions in the Great Plain of their transport infrastructure, as a result of which the railroad ring now lay outside Hungary, and networks with central places as their destination were bisected by the newly designated borders.

In summary, the evolution of the peripheries was attributable to two main factors:

- the first was that the centres of the regions concerned were now outside Hungary,

- the second was that these areas, which used to be deep inside pre-Trianon Hungary, were now border areas along the newly defined borders.

It was, therefore, no coincidence that these regions had difficulty in redefining themselves in the economy and their integration into the regional 
division of labour was also fraught with difficulties (Beluszky, referenced by Jász 2006).

We shall now go on to outline, in a breakdown by eras, the 'contribution' made by economic and spatial planning policy in Hungary to the highly polarised development experienced over the past 60 years or so.

Relying on a paper by Nemes Nagy József and Dövényi Zoltán (Nemes, Nagy, Dövényi 2003), we will expand our perspective in order to study spatial processes from the end of World War II to the present.

\section{The Hungarian adoption of the Soviet model (1948-1968)}

A key characteristic of this era was that the industrialisation of rural areas functioned as spatial development, which was practically non-existent, even as an incidental or minor policy. Economic priority no. 1 was the quantitative increase in the production of goods, where the development of heavy industry took precedence. Little emphasis was placed on the development of infrastructure, key to the development of settlements and the quality of life of their residents; the only progress made was rural electrification (the electrification of villages). Alongside this, forced industrialisation and the collectivisation of agriculture led to significant internal migration from rural areas to Budapest and the centres of heavy industry. This process adversely affected demographic composition, especially that of villages, as well as the social structure of towns/cities as destinations of migration.

\section{The Hungarian Model (1968-1982)}

During this period as an outcome of investments, though slowly, some equalisation of household incomes started to materialise at regional level. However, by the mid-70's the funds earmarked for extensive development had slowed down to a trickle, which precipitated a serious peripherisation in the settlement network, which mainly manifested itself at the small regional level. Two of the underlying reasons for this were the establishment of town-plusdistrict units and the closing of railway lines handling low traffic volumes.

Overall, the era can be characterised by strong differentiation at the regional and settlement levels against a backdrop of equalisation trends at the large regional level. 


\section{The crisis of the system (1982-89)}

The scarcity of development funds had become even more conspicuous by the 1980's; however, their effects across the country were still uneven. The lack of funds hit those areas hardest where the local economy had depended on a single industry. This is when depressed regions, key to the understanding of social exclusion, began to emerge.

Large companies were still key economic factors in that era. They responded to the problems that recession had brought to the surface by shifting the burden of their crisis onto peripheries through various measures. One such common measure was the closing down of their premises in the provinces, often in regions where they were the only major employer. The other was the laying-off of commuting employees mainly from regions on the outer and inner peripheries.

Relying on a parliamentary decree in 1985, the government set as an objective the convergence of the regions that had, by that time, been identified as unequivocally disadvantaged. However, due to lack of time and the necessary development funds, this convergence failed to materialise.

\section{Spatial processes after the political changeover}

The relative social equality, an outcome of the policy of an equality drive in the socialist era, soon disappeared due to the dramatic changes that came after the 1990's, with inequality between the upper ten percent of the population and those at the very bottom of the social ladder assuming unprecedented proportions. Poverty had become a factor capable of shaping settlements (Dövényi 2003). Nearly 1.5 million jobs were cut across the country, which was the primary cause of a dramatic increase in short-term poverty.

The period that has passed since the political changeover is not a consistent whole: the first half was a time of decline and crisis, while the second that of equalisation and consolidation as dominant processes for the entire society. Unfortunately, Hungary is again likely to face the social problems of the early 1990's, due to the decline that started in 2006 and has been amplified by the global crisis. We have never had reasons for optimism as regards spatial processes, as processes ensuring permanent spatial equalisation have never been set in motion. 
Owing to the large spatial discrepancies of development, we are now witnessing the appearance of a new generation of social problems. Quite clearly, a settlement's development potential now depends on its geographical location (Dövényi 2003).

So far we have described the policy to be blamed for inequalities, which is a source of spatial disadvantages and one of the factors responsible for social exclusion. Next, we shall analyse ethnicity from the perspective of the role it has played in the emergence of what is known as a multiple disadvantaged situation.

Map 1: The proportion of the Roma population in Hungary's micro regions (2001)

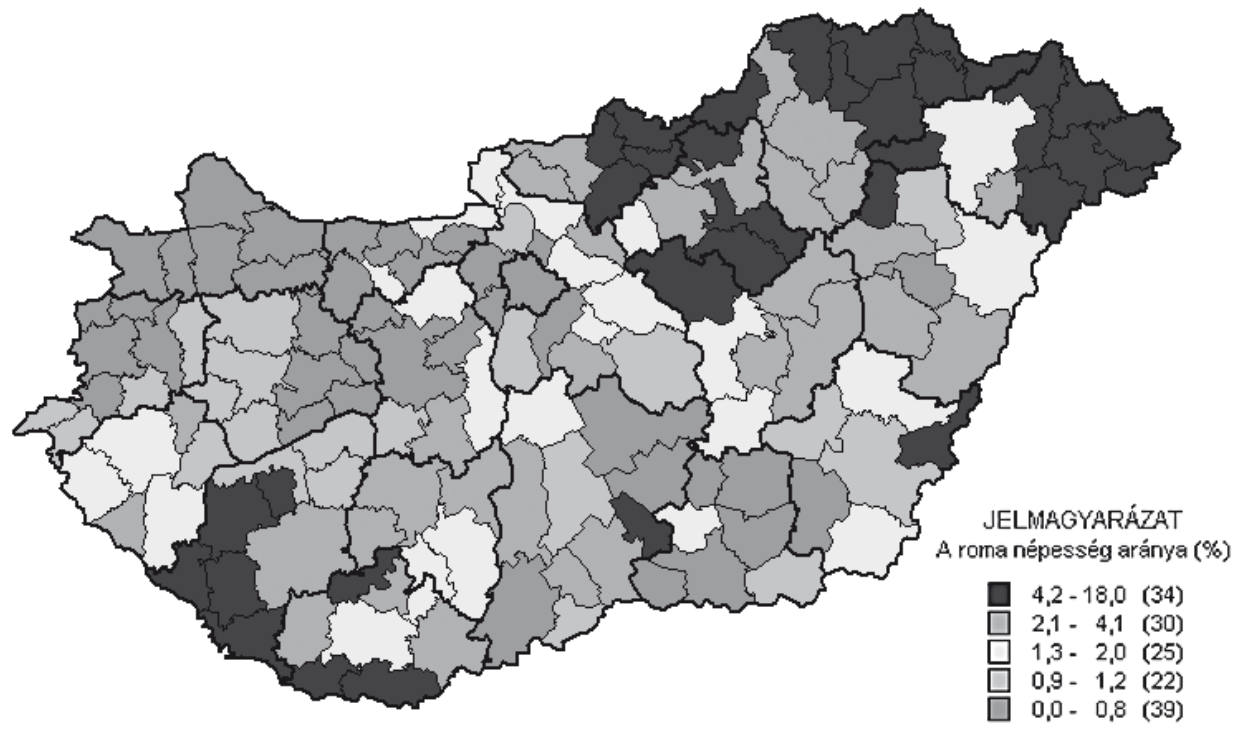

Source: Edited by the author based on Balcsók I. 2006. p. 110.

The extent and manner of the social exclusion of the Roma people in Hungary have undergone a number of changes over the centuries. However, it was not before the last century that a significant Roma underclass developed. The term does not apply to Hungary's Roma population as a whole, but to groups living in ghettoes with multiple disadvantages. Those in an underclass 
are undoubtedly excluded socially; however, exclusion today is completely different from what it used to be (Ladányi and Szelényi 2002). Ethnicity is not a factor leading to social exclusion for the social groups which are poor along one dimension only, or whose problems are temporary and mainly of an economic nature. The major difference between these social groups and the Roma underclass is that in the case of the latter there is a line of demarcation of ethnic origin between it and mainstream society.

A comparative study by János Ladányi and Iván Szelényi of the Roma people in Central and Southern Europe (Ladányi and Szelényi 2002) reveals that the line of demarcation between it and mainstream society is sharpest in Hungary.

We will attempt to provide an overview of the background to the evolution of the Roma underclass in Hungary. The retrospective review covers a period from after World War II to the present, because these are the very decades that precipitated events and unexpected twists in them that are to be blamed most for the social exclusion of the majority of the Roma in Hungary.

The emergence of the underclass and, within that, ethnicity and the unequal spatial development outlined above are closely interrelated. The decline of the areas with small-size villages, a target area for the underclass started with collectivisation, which led to agricultural production taking an increasingly low profile.

This process was further accelerated by a settlement and spatial development policy prioritising the development of raw material intensive industries and, hence, centres of heavy industry, the capital city and county seats. The above processes, generating significant outbound migration in the 1960's and 1970's, contributed, to a large extent, to the current demographic losses of areas with mainly small villages. However, the chief ideologists of the political regime failed to foresee that real estate, which had thus lost its real value, and was now available for a song, was to turn areas with mainly small villages and inner peripheries into target areas for (destinations of) inbound migration. A loss of function of these places due to the establishment of town-plus-district units prompted professionals to flee. As a result, the aging 'old poor' unable to sell their real estate, the arriving Roma with multiple disadvantages and a non-Roma underclass made up the majority of the population in micro- and small villages. Thus, a truncated society was left behind, with no model groups facilitating the integration of those falling behind (Ladányi and Szelényi 2002). The majority of Roma settling down in micro- and small villages used to live in Roma shanty towns. 
Though in the 1970's the government made serious efforts to demolish the shanty towns, the result was a curate's egg. Nor was the 'Cs Housing Project' able to improve the living standards of the Roma, because houses came with a small floor area and were of inferior quality. There were often serious clashes between the local population and the newcomers (i.e. the Roma and other disadvantaged social groups) intending to settle down, which took an increasingly extreme form after the political changeover.

Researchers seem to agree that the policy of assimilation in the pre-regime change era also brought about favourable changes in the daily life of the Roma and narrowed the gap between the Roma and the non-Roma. It was in the era of state socialism that Roma children started to go to school regularly. However, we should hasten to add that they were often referred to remedial schools or all-Roma classes. Another achievement of the era was $80 \%$ male and $60 \%$ female employment among the Roma, enabling them to embark on a path of modernisation and civilisation (Ferge 2002).

The integration of the Roma into mainstream society has, however, proved temporary, and a number of unfavourable trends that appeared after the political changeover have turned out to have their roots in state socialism. Forced assimilation had further long-term consequences, in addition to those presented above: it interfered with and eroded traditional Roma relations. Therefore, those who could not adjust to the prevailing status quo or secure a firm place in the society of the time were destined to slip into the underclass (Ladányi and Szelényi 2002). The political changeover interfered with this process, which, though riddled with contradictions and anomalies, resulted in some convergence. This interference drove a huge number of the Roma to isolated micro-villages and urban slums. Micro- and small villages were unable to deal with the shock of social restructuring, with their residents becoming unemployed on a massive scale (Szalai 2002). Based on the changes since and their consequences, it is safe to say that the biggest losers of the political changeover in Hungary are the Roma.

Naturally, the switch to the market economy did not affect all Roma groups in the same way; middle-class Roma were able to capitalise on the advantages offered by the new circumstances. Some gentrification seems to have started among them as well, with a middle class emerging; however, the distance, both literally and figuratively, between the Roma capable of catching up with mainstream society and members of the underclass is growing. Today one of

${ }^{1}$ Here the Hungarian 'Cs' stands for low or reduced quality. 
the most difficult problems of an ethnic nature is that a large majority of the Hungarian population - according to researchers around 30\% - perceive the Roma as unwanted and regard them as scapegoats. This is a major change compared with an earlier, pre-regime change situation where, despite their problems and poverty, the Roma were considered to be part of the local labour force, and there was demand on the part of the majority for Roma labour. The fact that since 1990 entire settlements have become Roma ghettoes has resulted in the Roma almost completely losing touch with mainstream society, and the emergence of lopsided local societies, which we discussed in an earlier paper (Ladányi and Szelényi 2004). In order for segregation of this kind to be managed, further so-called active social policy measures, such as the social land project, aimed at the social and labour market integration of the Hungarian Roma should be taken (Jász and Szoboszlai 2005). Unfortunately, we are witnessing exactly the opposite in Hungary right now.

Nowadays only a quarter of the Hungarian Roma are not excluded from some perspective or other. Nearly $25 \%$ are subject to residential, labour market or educational exclusion. Close to a quarter have been undergoing gentrification. $40 \%$ of the Hungarian Roma belong to the underclass discussed in a paper (Ladányi and Szelényi 2004). They are threatened by both poverty and permanent social exclusion passed down from father to son. Their chances of integration into mainstream society are slim. What makes recovery from the current situation especially difficult for them is the loss of skills and connections.

\section{The Different Facets of Social Exclusion in the Seven Regions of Hungary}

Before 2004, the fact that consistent and regularly provided regional data needed for the analysis of exclusion and its consequences, and for measures aimed at integration were unavailable rendered addressing the exclusion issue in Hungary difficult. Things changed when a consistent study aimed at exploring the characteristics of the social welfare system was started by the National Institute for Family and Social Policy ${ }^{2}$. The study was carried out in co-operation with regional resource centres and the involvement of regional experts with my participation in the North Great Plain region. In the course of the study we relied on questionnaire surveys, statistical data collection and

2 Today called the Institute for Social Policy and Labour. 
in-depth interviews in order to identify the regional characteristics of social exclusion and substantiate our hypothesis that differences in the social and economic characteristics of the Hungarian regions accentuate different aspects of this phenomenon. In the following section we will summarise the findings of this study.

\section{Map 2: Hungary's regions}

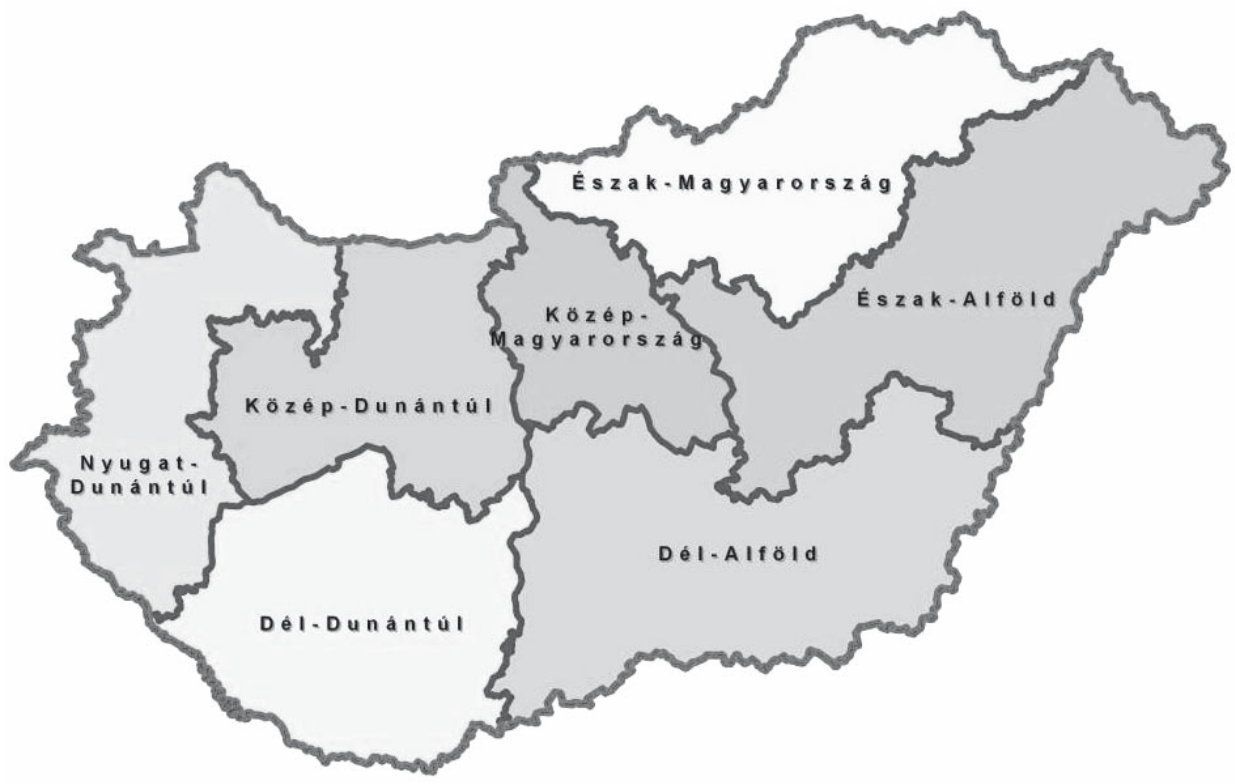

Source: www.terport.hu

Due to lack of space, we will confine ourselves to providing a list of special characteristics of the Hungarian regions in terms of social exclusion, arguing that interventions with a different focus are perfectly justified owing to them having such differing characteristics ${ }^{3}$.

- Southern Great Plain Region (Dél-Alföld): social exclusion mainly affects aging residents living alone in regions with scattered farmsteads and in border regions; multiple disadvantages are primarily due to difficult

${ }^{3}$ Documents serving as sources of summary: shortened working versions of regional analyses. 
geographical access and a scarcity of public utilities; a significantly high proportion of persons with addiction and mental disorders, with a marked presence of various forms of deviance;

- Central Hungarian Region (Közép-Magyarország): phenomena arising from unaddressed social problems, homelessness in particular, are concentrated here; as a result, certain zones are undergoing ghettoisation; furthermore, the indigenous poor who live in dynamically developing settlements and receive practically no social support continue to pose a real challenge to the social welfare system;

- Southern Transdanubia Region (Dél-Dunántúl): a settlement structure where small villages are dominant, the isolation, in both relative and absolute terms, of townships and the overrepresentation of the Roma population in some regions ${ }^{4}$ have all contributed to the current peripheral status of the region; a low level of schooling and the region's peripheral status from the perspective of accessibility reinforce each other;

- Northern Hungarian Region (Észak.Magyarország): child poverty is the most serious problem facing the region; the presence of ethnicity-based segregation is also strong; the social welfare system available to local residents is run by persons working either part-time or on their own;

- Central Transdanubia Region (Közép-Dunántúl): one of the Hungarian regions where a favourable economic and employment situation does not improve social chances evenly, i.e. an economically advantageous situation does not automatically translate into social advantages for disadvantaged groups; the proportion of the indigenous poor with a low level of schooling and living a long way from zones of development is also high here;

- Western Transdanubia Region (Nyugat-Dunántúl): residents in problem regions hidden behind macro-data often remain 'invisible' for a social welfare system that has not been properly developed; compared to the national average, the cost of living is very high in the region; as a result, the proportion hit by expenditure and consumption poverty is increasingly high;

4 This paper uses the terms 'Gypsy' and 'Roma'. The official designation of the ethnic minority group is 'Gypsy', while daily parlance uses the more presentable and politically correct 'Roma'. The word 'Roma' originates from the word 'rom' meaning 'man' in the Lovari language. As, from among the Roma ethnic groups living in Hungary, the Beás group does not speak Lovári, many of them prefer to use the word 'Gypsy' The same also applies to some Romungros. Both terms are used in today's academic and public parlance alike. 
- North Great Plain Region (Észak-Alföld): It is here that the number and size of areas that are worst hit by social exclusion are the largest. Of the factors giving rise to the emergence of social exclusion, here in Hungary spatial disadvantages and ethnicity are the most important.

\section{A few recent measures to mitigate spatial disadvantages}

Although since the political changeover Hungary's successive governments have all acknowledged the need for mitigating spatial differences, in practice, spatial development has been a failure. A major development in the management of spatial inequalities occurred in 2007, when the government, relying on statistical data revealing differences in the level of development, identified the 33 most disadvantaged micro regions, home to 1 million people, in Hungary. (At the same time, 14 disadvantaged micro regions were also identified.)

The map below shows the location of the 33 most disadvantaged small regions:

\section{Map 3: Hungary's 33 most disadvantaged micro regions}

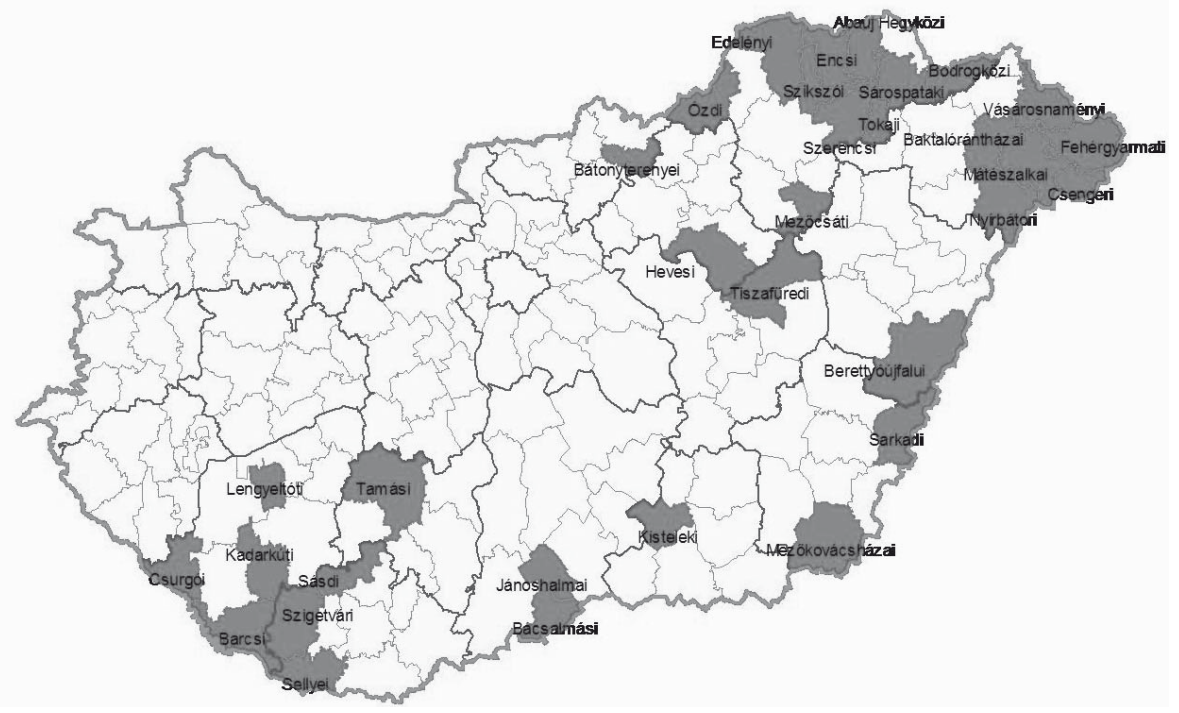

Source: www.nfü.hu

After the small regions had been identified, a series of programmes entitled 'We will not give up on anybody!' were launched. They were complex flagship projects aimed at invigorating the local economy, boosting employment and 
social and geographical mobility facilitated in the 33 most disadvantaged micro regions. In order that the micro regions most blighted by social and economic problems can have access to the earmarked funds of the European Union, taking into account a shortage of professionals and experts, the government provides programming support for local communities enabling them to reach the most successful possible tendering activity.

There were also centrally launched programmes aimed at improving employment in micro regions. One such programme in adult education was the 'One Step Forward' programme or the 'START' card facilitating employment, and the 'START REGION' card was tailor-made for these regions.

As well as the Roma, children are the greatest victims of poverty in rural areas. Today, one in four children in Hungary is poor. In order to lessen child poverty, a programme entitled 'Combating Child Poverty National Programme' was worked out. The objective of the programme is to reduce the poverty rate among children and their families significantly in Hungary, whereby children's perspectives can be incorporated in such a way that the impact of multiple factors is reduced. The priorities of the programme also include substantially mitigating the extreme forms of exclusion, segregation and deep poverty. Based on the programme, the 'Let's Make It Better For Children National Strategy' was worked out in 2007 and approved by the Hungarian Parliament the same year. The strategy sets an example in underscoring the importance of the need for a complex approach and complex services as the only way in which exclusion can be tackled effectively. Currently, in order for the feasibility of the above to be assessed, a pilot project is currently under way in the Szécsény micro region of Nógrád County in North Hungary Region.

Dovetailed to the strategy and based on UK models, the 'Safe Start' programmes are also expected to help reduce the social exclusion of children aged 0 to 5 year(s) and their parents in the economically most challenged micro regions.

A brief look at trends in poverty in rural areas reveals that in Hungary, too, the need for intervention measures is the most pressing issue in the area of education and job creation. A comparison of the map below with the chart showing the 33 most disadvantaged micro regions reveals a clear causal link between a disadvantaged situation and a low level of schooling. 
Map 4: The percentage of those not even passing the first grade in the population over 7 years of age

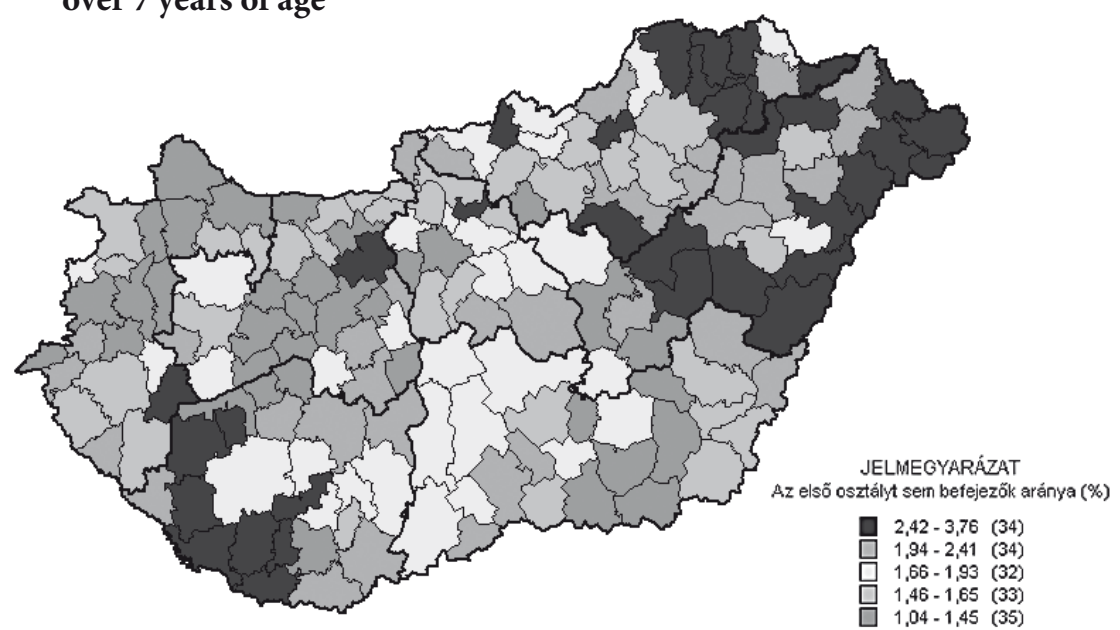

Source: Edited by the author on the basis of Balcsók I’s chart p. 141, 2006.

The same applies to unemployment. The chart below confirms that no favourable change of note occurred in the unemployment rate in the most disadvantaged regions.

Map 5: Changes in the relative unemployment indicator (compared with the national average) in a breakdown by micro regions (20 December, 1992)

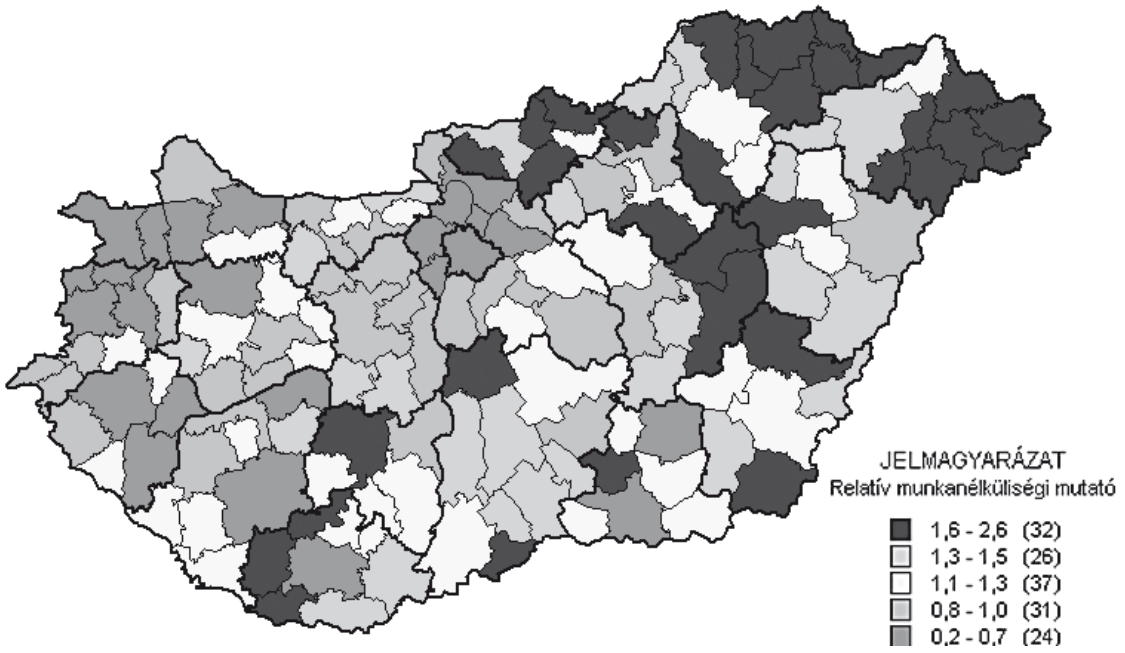

Source: Balcsók, 2005. p. 72. 
Map 6: The average value of the national ranking of the individual micro regions calculated on the basis of the unemployment indicator (1992 and 2008)

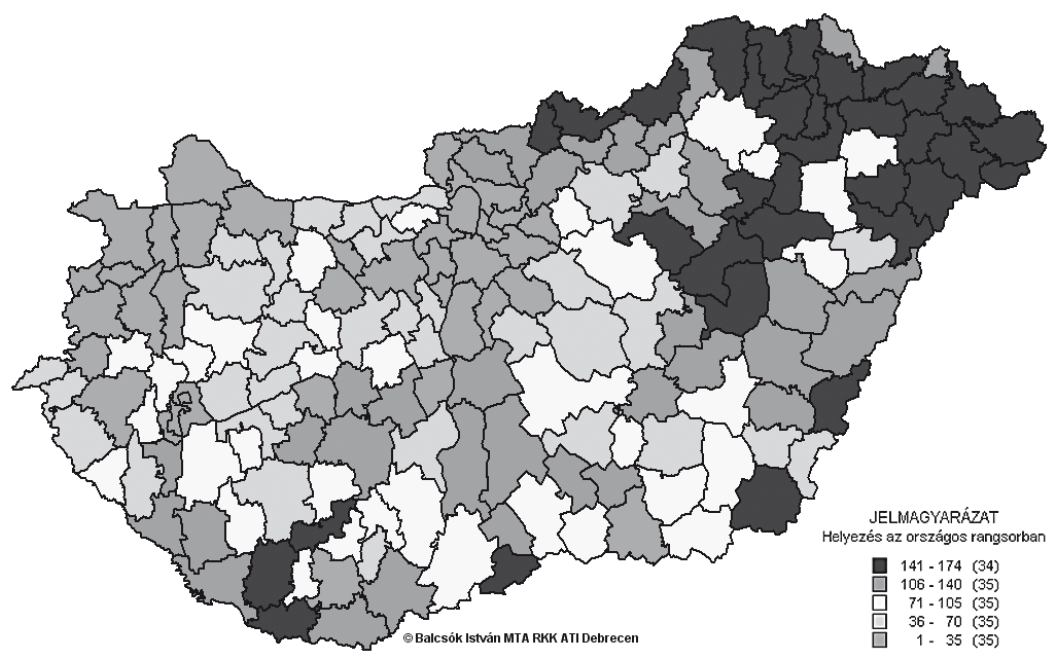

Source: Balcsók, 2009. Edited on the basis of the data sets of the Public Employment Service

The charts reveal that out of the 30 micro regions with the most unfavourable indicators in 1992, 20 belonged to the same category even after 16 years.

As regards the social welfare system that is intended to tackle poverty and exclusion, the impact of the settlement slope can be felt in Hungary. Although, from a statistical data perspective, the service coverage ratio does not look at all bad in respect of primary social care in the most disadvantaged regions, due, in part, to the fact that care is provided by multi-objective partnerships introduced in 2004, our studies (Jász 2006) provide evidence that the figures gloss over serious problems. The workload on social workers is often enormous; they often burn out, and services are often provided by one person. The less developed a region that we studied was, the more acutely this phenomenon was felt. Local representatives of the social welfare sector hardly have any say in the planning processes that influence local social policy; fatigue, caused by too much bureaucracy, rules out the provision of efficient mental support for those excluded in most cases.

There is no regular co-operation worthy of mention between the staff of the networks established by various ministries, intended to facilitate local developments and linked to rural and spatial development in areas where the most important task is to establish a network for those affected by exclusion 
and to find persons who can inspire communities. In order for unemployment to be tackled more effectively, the provision of integrated services launched in 2007, afterwards abandoned, should be re-launched. This would require regular co-operation between the actors in charge of labour affairs and those of the social sector, primarily concerning permanent unemployment leading to exclusion. This is underpinned by the fact that the rate of those permanently unemployed among the unemployed is the highest (48\%) in Hungary. There has been a dramatic increase in the proportion of young career starters whose parents do not work in the primary labour market.

Unfortunately, no encouraging news of the above integration programmes has surfaced yet; it should be added, though, that some analyses have yet to be conducted on the results of the various experiments/surveys. My personal experience is that the poor political decisions of the past decades, described above, have led to such a loss of trust and such a degree of indifference among those living on the peripheries that not even the current (improved) access to funds can tackle apathy and indifference in the most disadvantaged regions. Despite the objectives that could easily justify the launch of convergence programmes, no local programming or developing groups capable of working together in the long term have yet emerged. Instead, mostly external experts (for the want of internal ones, due to the outbound migration of the professional classes) do some ad hoc brainstorming. Unfortunately, most existing visions lack a complex approach and innovation - a trend since the 1st National Development Plan 2004-2006. In order to change this situation, a change in attitude and social support would be required, the chances of which seem, alas, rather slim.

In order to tackle poverty and social exclusion in rural areas, cohesion policy that also includes development policy should - as the Barca Report published a few months ago suggests - be based on new foundations in Europe as well. Unless social exclusion is treated as a priority - the pre-conditions of which is the earliest possible working out of the relevant definitions and the necessary indicators - differences in living standards will continue to grow in both Hungary and other EU member states. The latter trend suggests a much more unfavourable trend than what the GDP picture of regional differences does.

An attempt to conclude the impact of two collective factors, regionalism and ethnicity on occurrence of people's disadvantages living in rural areas have been made before. Carry out of focused status reports on micro level 
is obviously reasonable in Hungary compared to other EU member states, in order to ensure a solid base for implementation of regionally different cohesion programmes. The regional aspect should be involved in policies playing a dominant role in the mitigation of poverty and exclusion, such as education, employment, healthcare and social policy. Considering the latter, it is justified that the Method of Open Coordination is a useful, yet not sufficient means for moderating exclusion. Purely adapting foreign models as well as executing regional development policies neglect regional and ethnic diversity, reduction of disadvantages of rural inhabitants remains unreachable. Added to the above mentioned prerequisites a real monitoring approach assisting project fulfilment, a close cooperation of regional development and social policy actors in regional planning, as well as a definite commitment of local decision makers are needed for avoiding the further escalation of exclusion.

Partly due to the lack of professionals' competence assistance networks operate wastefully and with low efficiency. Education of regional dimension and ethnic specialities should be more emphasised in pedagogical curricula of institutions engaged in professional training for assistants in order to eliminate inadequacies.

\section{References}

Balcsók, I. 2006 A munkanélküliség területi egyenlötlenségei és legjellemzöbb folyamatainak alakulása az 1992-2002 közötti idöszakban [Spatial Inequalities of and Major Trends in Unemployment between 1992 and 2002]. A PhD thesis. Debrecen: Debrecen University, p. 158.

Dövényi, Z. 2003 A településrendszer fejlödése és sajátosságai [Development and Characteristics of the Settlement System] In Perczel, G. (Ed.) Hungary's Socioeconomic Geography. Budapest: ELTE Eötvös Publishers, pp. 521-528.

Faluvégi, A. 2004 Térbeli kirekesztödés, a térségek leszakadása [Spatial Exclusion and

Divergence of Regions] In Monostori, J. (Ed.), Poverty and the Process of Social Exclusion. Budapest: CSO, pp. 197-223.

Ferge, Zs. 2002 Struktúra és egyenlötlenségek a régi államszocializmusban és az újkapitalizmusban [Structure and Inequalities in Old State Socialist and New Capitalism] Szociológiai Szemle. No 4: 9-33.

Jász, K. And Szoboszlai, Zs. 2005 Socially Excluded Groups in Hungary and a Special Re-integration Programme. In Hungarian Spaces and Places. Patterns of Transition. Pécs: Centre for Regional Studies, pp. 274-289. 
Jász, K. 2006 A társadalmi kirekesztödés térbeli sajátosságai az Észak-Alföldi Régióban [Spatial Characteristics of Social Exclusion in the Northern Great Plain Region] A PhD thesis, PTE, Földtudományok Doktori Iskola, p. 175.

Ladányi, J. and Szelényi, I. 2002 Cigányok és szegények Magyarországon, Romániában és Bulgáriában [The Roma and the Poor in Hungary, Romania and Bulgaria] Szociológiai Szemle. No 4: 72-95.

Ladányi, J. and Szelényi, I. 2004 A kirekesztettség változó formái [Changing Forms of Exclusion] Budapest: Napvilág Publishers, p. 201.

Littlewood, P. 1999 Social Exclusion in Europe. Problems and paradigms. London: Ashgate.

Nemes Nagy, J. 2003 Regionális folyamatok [Regional Processes] In: Perczel, G. (Ed.), Hungary's Socio-economic Geography. Budapest: ELTE Eötvös Publishers, pp. 565-569.

Szalai, J. 2002 A társadalmi kirekesztödés egyes kérdései az ezredforduló Magyarországán

[Some Issues of Social Exclusion in Hungary at the Turn of the Millennium] Szociológiai Szemle. No 4:34-51.

A hét magyarországi régió szociális helyzetfeltárásának rövidített változata [A Summary of the Social Situation Assessment of Hungary's Seven Regions] 2004. National Institute for Families and Social Policy, Manuscript.

A regionális szintü szociális tervezési kapacitások megerösitése, állapotfelmérés, módszertani ajánlás [Increasing Regional-level Social Planning Capacities. A Situation Assessment and Recommended Methodology] 2004 Szolnok: HAS CRR GPRI Szolnok Group of Sociologists.

Combating Poverty and Social Exclusion in Rural Areas: http://ec.europa.eu/social/ main.jsp?catId $=88 \&$ langId $=$ en\&eventsId $=158$ 